European Journal of Pragmatism and American Philosophy

$\mid-1 / 2$ | 2009

Europe and American Pragmatism: Influences and Interactions

\title{
Nietzsche and James
}

A Pragmatist Hermeneutics

\section{Rossella Fabbrichesi}

\section{(2) OpenEdition}

Electronic version

URL: http://journals.openedition.org/ejpap/962

DOI: 10.4000/ejpap.962

ISSN: 2036-4091

\section{Publisher}

Associazione Pragma

\section{Electronic reference}

Rossella Fabbrichesi, « Nietzsche and James », European Journal of Pragmatism and American Philosophy [Online], I-1/2 | 2009, Online since 01 July 2009, connection on 30 April 2019. URL : http:// journals.openedition.org/ejpap/962 ; DOI : 10.4000/ejpap.962

This text was automatically generated on 30 April 2019.

\section{c) (†) $९$}

Author retains copyright and grants the European Journal of Pragmatism and American Philosophy right of first publication with the work simultaneously licensed under a Creative Commons AttributionNonCommercial-NoDerivatives 4.0 International License. 


\title{
Nietzsche and James
}

\author{
A Pragmatist Hermeneutics
}

\author{
Rossella Fabbrichesi
}

\section{Introduction}

1 The continental - German for the most past - strand of classical hermeneutics and the typically Anglo-Saxon school of American pragmatism have more than one point in common, something which only some contemporary critics - the most famous of which is certainly Rorty - have noticed. To be honest, these possible convergences are considered with suspicion, maybe due to the extreme divergence of the two schools of thought that they refer to. The methods, the disciplinary orientations, the languages, the cultural environments in which the respective representatives work are, in fact, too distant the one from the other.

2 Nevertheless, there is a basic shared inspiration between the two philosophical perspectives that is recognisable and comparable under many respects. ${ }^{1}$ Be this shared inspiration a way of thinking common to a great part of twentieth century thought; or be it instead an actual consonance of perspectives, as a matter of fact hermeneutics and pragmatism resonate together, often echoing each other when reflecting on themes like truth, objectivity, belief, and value. This common intonation is the object of this article, thus introducing one of the themes that characterize the aims of this journal: the comparison of the different philosophical traditions developed on the two opposite sides of the Atlantic. ${ }^{2}$

3 I will start simply with some quotations:

"Of what alone can knowledge consist? - "Interpretation": The introduction of sense into things, not 'explanation' (in the majority of the cases a new interpretation of an old interpretation which has grown incomprehensible and has become little more than a mere sign). There is no such thing as an established fact, everything fluctuates, everything is intangible, yielding; after all, the most lasting of all things are our opinions." ${ }^{3}$ (WP 604) 
"In opposition to Positivism, which halts at phenomena and says, 'These are only facts and nothing more,' I would say: No, facts are precisely what is lacking, all that exists consists of interpretations. We cannot establish any fact 'in itself': it may even be nonsense to desire to do such a thing. [...] To the extent to which knowledge has any sense at all, the world is knowable: but it may be interpreted differently, it has not one sense behind it, but hundreds of senses. - 'Perspectivity'." (WP 481)

"Beliefs are themselves parts of the sum total of the world's experience, and become matter, therefore, for the next day's funding operations [...] In the realm of truth- processes facts come independently and determine our beliefs provisionally. But these beliefs make us act, and as fast as they do so, they bring into sight or into existence new facts which re-determine the beliefs accordingly. So the whole coil and ball of truth, as it rolls up, is the product of a double influence. Truths emerge from facts; but they dip forward into facts again and add to them; which facts again create or reveal new truths (the word is indifferent) and so on indefinitely. The 'facts' themselves meanwhile are not true. They simply are. Truth is the function of the beliefs that start and terminate among them [...] What we say about reality thus depends on the perspective into which we throw it." (P 107-8) ${ }^{4}$

4 Truth and perspective: these are essentially the themes at stake. The issue that troubled James - and that, we should add, did not trouble Peirce too much, since his interest focused on logical meaning - is actually truth or, to use a Nietzschean expression, will to truth. In other words, the theme is thus declined: which function has truth in our lives? Why do we consider to know and to know the truth better than not to know? I will focus amongst the many possible comparable themes I could choose - on this aspect of the two doctrines.

\section{Truth as Perspective}

5 Let us start from the statement - taken from one of his most important works - that James soberly proposes in the previous quotation, according to which truth is circular and perspectival and reality coincides with the totality of beliefs that denote it as such. As it is easy to notice, there are here extraordinary assonances with the Nietzschean vituperated expression - blamed by many as relativism and nihilism -, according to which we live dazzled, persuaded of the existence of concrete "things in themselves," the "truth" of which it would be our task to look for. Certainly James does not reach the point of saying that there are no facts, only interpretations; but we can also state with a high degree of certainty that neither Nietzsche should be interpreted under the simplistic partly Idealist and partly Gascon - image apparently transpiring from The Will to power. ${ }^{5}$ To better penetrate Nietzsche's thought let us take an example ${ }^{6}$ that Peirce and James would have probably appreciated, since it comes from biology, the elective science in mid-nineteenth century intellectual landscape, in which the two pragmatist friends were educated. The example involves the universe of ticks, small and annoying animals that as it is known - react to only three sensible stimuli: light, warmth and smell. Every tick stays on a branch, sometimes for years, attracted by a particularly well-lit place (first fundamental index of their vital praxis); it stays there absolutely static and amorphous, until an animal with a certain type of smell happens to walk below it. This is the second sign of the 'world' to be perceived: an olfactory sign. A 'world' in the form of animal reek. Once the tick has fallen on to the back of the mentioned beast, it tries to crawl to the place least covered in fur in order to penetrate it: and here is the third stimulus that the tick welcomes from the world, a tactile one. That is all: of a world bustling with colours, 
smells, forms, sounds, flavours, screams, events, and movements, the tick extracts three things only: light, a certain smell, a certain temperature. The tick selects them, elevates them to absolutes and it does not seem to see anything else of that which is 'the world' for us. But is this a subtraction from or instead a perfection of the (biological) being? Is the world of the tick the same as our own world? The great German naturalist Jacob von Uexküll grasped this point with extreme acuteness: "we can no longer speak of the single sun, shining in the sky, but must speak of thousands upon thousands of suns. [...] The sun that makes a swarm of gnats dance is not our sun but a gnat sun, which owes its existence to the eye of the gnat."7 Thus, it is not the same world seen from different points of view, but a different world. Here is - in plain words - the reference to hermeneutic principles based not on a trivial relativism or an interpretive subjectivism, but on the biological functions that ground the cognitive impulse. As many authors have already demonstrated, ${ }^{8}$ Nietzsche's perspectivity is deeply rooted in a similar reasoning. In The Will to Power we can read: "It is our need that interpret the world; our instincts and their impulses for and against. Every instinct is a sort of thirst for power; each has its point of view, which it would fain impose upon all the other instincts as their norm" (WP 481).

In other passages, Nietzsche clarifies that it is possible to define knowledge as truth only by referring to the rigorously "biological and anthropocentric" reasons thanks to which "every centre of power - and not man alone - constructs the rest of the world from its point of view - that is to say measures it, feels it, and moulds it according to its degree of strength," that is to say assumes perspectives (WP 636). In this way, we are already far from the "intellectualist" reading according to which perspective is an act of pure mental apprehension that - from a certain point of view - contemplates the truth of things, and this apprehension is being deemed as always unavoidably relative, since such a perspectival glimpse can never grasp the "being-in-itself" in its wholeness. This relativism can be defined as "nostalgic": it always maintains regret for the absolute that while existing somewhere - is inaccessible to the part. But here Nietzsche simply says: each perspective is determined by our need, by our practical and physiological instincts, and to live means to be "partial," to be (in) perspective, without being able to be situated in different perspectives, and even less in panoramic ones. In more explicit words: "The things-in-itself is nonsense. If I think all the 'relations,' all the 'qualities,' all the 'activities' of a thing, away, the thing itself does not remain: for the 'thingness' was only invented fancifully by us to meet certain logical needs - that is to say, for the purposes of definition and comprehension (in order to correlate that multitude of relations, qualities, and activities)" (WP 558). It is only in this sense that there are no "facts": if we delete the difference between being and knowability - as also Peirce's writings from 1868 attempted to do - we do not have either facts, or - in a strict sense - perspectives on facts: "As if a world could remain over, when the point of view is cancelled!" (WP 567).

7 If we make the real world disappear, the apparent world disappears also. Nietzsche is very clear about this point: if we eliminate metaphysical dualisms, with the idea of "initself" also the idea of "for me" disappears, that is, the opposition between absolute and relative disappears (is the "poor" world of the tick experienced as lacking of anything? That world is - in its poor relativity - absolutely perfect). Finally - Nietzsche states - a shapeless flux appears to us as a "fact" only when we are able to give a meaning to it (WP 556); even the word "fact" refers to the concept of action, to something that is man-made, produced. To talk of facts, of things in themselves is simply another interpretation, a perspective amongst the many others through which we can look at the world. ${ }^{9}$ 
This position is, as previously mentioned, represented with equal incisiveness - but maybe with more caution and some incoherence - in James' writings. In his seventh conference, titled "Pragmatism and Humanism" - perhaps the most theoretical and radical of the eight that compose Pragmatism - James attacks Truth, this "perfect idol of the rationalistic mind!" (P 115), clarifying - in a way that Nietzsche would have appreciated - that the question: "Which is the truth?" is "irrelative to all conditions" for any possible answer. It should not thus be considered as a real question, moved by a real doubt (a genuinely irritating one, that has an influence on our lives - as Peirce argued). Truth is always declined in the plural, it is not that which is in relation to something existent, "out there," or to something that was, but it is that which is in relation to something that still does not exist, that is in formation. "Philosophy has the natural tendency to want that truth is facing backwards, according to James it looks in front of us." 10 Thus truth "is not found, but manufactured" (ivi), not a discovery, but an invention; facts are, indeed, artifacts, created, produced (P 143). Truth ripens, as a fruit. It is constantly constituting itself and proliferating, like a coral.

9 Moreover - following the formulation of Ferdinand Canning Schiller - James emphasises that truths have to be conceived as "man-made products," "abstract names for the results [...] of a certain process" (P 117); or better, as something that evolves with the progressing of our (individual and communitarian) life, in the same way as biological organisms evolve. In a Darwinian fashion, concepts emerge, impose themselves, blossom and decay. But if we can say this of truths, the same can be said of the so-called "facts": the world is plastic - James writes inspiring by Schiller's humanism -, "it is what we make of it" (ivi). No "thing-in-itself" exists, before us or without us. We produce as much "Reality" as we can believe but we do not find it already out there (P 118). James could not have read the notes of The Will to Power, but he would have certainly agreed with the following statement by Nietzsche: '“truth' is not something which is present and which has to be found and discovered; it is something which has to be created and which gives its name to a process [...]. To introduce truth is a processus in infinitum, an active determining - it is not a process of becoming conscious of something, which in itself is fixed and determined" (WP 552). As an aside note: this - and nothing else than this - is for Nietzsche the meaning of the will to power: to replace being with value (WP 556 ${ }^{11}$ ), to stamp Being with the character of Becoming (WP 617).

10 In many passages James does not hesitate, it is true, to define himself as an "empiricist" and to underline the existence of sensible fluxes, stimulations and perceptions that invade us and that offer a resistance to our free creation of beliefs and opinions about what is real and what is not. "'Reality' in general is what truths have to take account of" (P 117), something independent from our will. James - exactly like Nietzsche - is not an idealist. But these indistinct fluxes of material that invade us "are neither true nor false; they simply are" (P 117). "That they are is undoubtedly beyond our control; but which we attend to, note, and make emphatic in our conclusions depends on our own interests" (P 118). For example - James writes - Waterloo pinpoints a Belgian location, with certain features, undeniably existing there and now. But for an Englishman it means victory, for a Frenchman it means defeat. For a European man it is there, with its geographically and anthropologically well-analysable features, for a tick it will be a certain ground light, a rugged and inhospitable territory. Which "fact" are we talking about?, Nietzsche would then ask him. And for whom, if not for us and for our interpretive tools, can this be defined a "fact"? 
11 Anyway, James again seems very close to these Nietzschean reflections in his conclusions: "What we say about reality thus depends on the perspective into which we throw it. The that of it is its own; but the what depends on the which; and the which depends on us" (P 118). Maybe Nietzsche would object that even the that is a function of the what, and that it does not "belong" to reality. But this scission of the being in event and meaning to use Carlo Sini's words ${ }^{12}$ - is attested in a clearly tragic way since Nietzsche's first writings. The frozen river of existence - as The Birth of Tragedy (1872) claims - flows horrendous and tumultuous: in order not to be reflected in its abyssal depth, we dress it in beautiful shapes, with colourful "[r]ubbish and gold dust of unconscious human vanity." Nevertheless, "[u]nderneath such flattering colours and repainted surfaces, we must once again recognize the terrifying basic text of homo natura" (BGE 143). ${ }^{13}$ In other words, Apollo is always one of Dionysus' names and Dionysus cannot appear if not "in figure." But he is there, with the "that of its own" terrible and incomprehensible. We hear the echo of this complementary duality in James, who - in the last pages of the conference - insists on the fact that it is not possible to deny that "All 'homes' are in finite experience; finite experience as such is homeless." There is a certain sensible flux, but "what is true of it seems from first to last to be largely a matter of our own creation" (P 122).

There is thus a circularity - do we want to define it as a hermeneutic circularity? between facts and beliefs, according to which human beings add constantly - through the actions of their lives - facts to the brute matter of existence. This retroactively shapes the interpretive forms themselves, redefining their contours. Matter could thus be conceived of à la Peirce as the cohesive order of our beliefs - consolidated and made inert by common sense - that come to be solidified in the course of tradition. "Reality" is thus continuously transformed by the beliefs and interpretations that lead us in actions, and actions, practical or theoretical, produce facts that were not even conceivable as such before.

If a reality independent from thought - that is from human action (P 118) - does not exist, how can we be sure to grasp truth? James does not let this question frighten him and again - answers it in a surprisingly Nietzschean way: "We may glimpse [reality], but we never grasp it; what we grasp is always some substitute for it which previous human thinking has peptinized and cooked for our consumption. If so vulgar an expression were allowed us, we might say that wherever we find it, it has been already faked" (P 119-20). In Nietzsche we can read: 'Dissimulation' increases in accordance with the rising order of rank among organic beings. In the inorganic world it seems to be entirely absent. - There power opposes power quite roughly - ruse begins in the organic world; plants are already masters of it. [...] Before 'thought' is possible, 'fancy' must first have done its work; the picturing of identical cases, of the seemingness of identity, is more primeval than the cognition of identity" (WP 544). Truth, in synthesis - as already the small but excellently written juvenile essay On Truth and Lies in a Nonmoral Sense ${ }^{14}$ warned - is but "[a] mobile army of metaphors, metonyms, and anthropomorphisms" and any concept is but "metaphors which are worn out and without sensuous power" (p. 235).

14 The fulcrum of the pragmatist proposal is but a few steps away from the dangerous Nietzschean "relativism," 15 and everything relies - like in Nietzsche - on the way of looking at the terms "truth" and "reality": "For rationalism reality is ready-made and complete from all eternity, while for pragmatism it is still in the making, and awaits part of its complexion from the future" (P 123). Reality is not certain and static, out there, but "still 
pursuing its adventures" (ivi) and, as in a creative and artistic process, we add, with the touch of our hands, the tint of colour that we prefer, the embossing that better seems to us to model the clay of the world, aware that we "rape" (ivi), embank and orient the sensible flux. Nietzsche thinks along exactly the same lines in On the Genealogy of Morals: "interpretation [is] forcing, adjusting, abbreviating, omitting, padding, inventing, falsifying." 16

To interpret is to select some aspects that are significative for our vital practices, James thinks. Thus the truth and rigour of our analysis does not descend from the capacity of reading and describing correctly any aspect of the phenomenon that we have in front of us (the that facing us), but it also depends on our purposes, interests, or points of view. Which of these aspects we consider "real," making it work as decisive in the conclusions of our reasoning, becomes a function of the interest that moves us towards knowledge (P 121). And, as Heidegger said, knowledge has an understanding-interpreting root and a pathic-emotive root that are always entrenched. Thus, the analytical motto "[i]t is true what can be demonstrated in a rigorous way" has already decided in favour of that very precise value that is rigour (thus to be conceived as a pre-judice), it has already set itself in a particular emotive situation, ready to start an "interested" understanding that defines objectivity, coherence, clarity, analyticity as unshakeable values. But if they have value - both Nietzsche and James state - it is because they work in our cognitive practices, in our scientific forms of life, not because they are absolute and universal truths. When a theorem is analysed, order is certainly to be preferred to disorder. But when we are in a relationship, the coherent asset of an ordered world, or the crystalline domain of the rigour as reference parameters quickly fade away: there are no true and fake loves, demonstrable and indemonstrable ones. Nietzsche noticed how wisdom, clarity and logic had been used as weapons against the ferociousness of instincts, from Socrates to Stoics, and beyond. The request for greater "objectivity" and coherence, the appeal to elaborate a disinterested theory, led by an imperturbable gaze, answers to a very specific interest, with its undeniably emotive tone.

Logical truths reflect their own eco-physiological ground, as Babich states; ${ }^{17}$ James' concept of interest and Nietzsche's concept of perspective have more than one point of connection and I believe that we can proceed along these lines and point out how Nietzsche bluntly develops pragmatist motives, and how James could be defined as a "perspectivist" in the sense that we have just sketched.

\section{Truth as Belief}

If - according to Nietzsche - being is identified with the value that we attribute to it, according to pragmatists being is always what is believed to be the way it is: it coincides thus with the opinion that is held of it, with the sign that indicates and nominates it. Again the theme of truth is at stake and the shadow of Sophistics on the domain of our logical concepts lengthens.

James - as we have seen - believes in a "genetic theory of what is meant by truth" (P 37): truth is in the doing, it evolves in the course of experience, it is a process that is unfolded in time, following the model of epigenesis, ${ }^{18}$ by assimilation and differentiation ("a minimum of jolt, a maximum of continuity" P 36), with no possibility to predict its outcomes. A true theory operates a "marriage-function" (P 37) between old and new parts of knowledge, grafting itself into the old stem of knowledge and modifying its nodes. ${ }^{19}$ 

action and for life, acting as a guide and a companion to our existence (P 34). It is possible, I think, to sum up James' thought - as expressed in the Pragmatism essays - in this way: a belief counts as true when it satisfies us, it pays, also, in the cash-value of the word, it gratifies us, is held as true, proves itself useful if considered true, functions in orienting us along the road of research, that is, is advantageous as related to our vital power. "If there were no good for life in true ideas, or if the knowledge of them were positively disadvantageous and false ideas the only useful ones, then the current notion that truth is divine and precious, and its pursuit a duty, could never have grown up" (P 42, emphasis mine). Thoughts - in this conception - are simply tools "at-hand," work instruments, almost a prosthesis of our vital organs that support the thousands of practical and theoretical operations we are daily involved in. An idea will be "verified" not when it agrees with an "external" object, but when it is able to put us "into such working touch with it as to handle either it or something connected with it better than if we disagreed" (P 102). Truth is only an "expedient" (P 106) that guides us through reality, and an experience that meets some experience in sight, and not necessarily will meet farther experience equally satisfactorily. "The possession of truth, here so far from being an end in itself, is only a preliminary means towards other vital satisfactions" (P 98). The line is not to be drawn between truth and lie, but between what is true (meaning what is relevant to the active praxis) and what is irrelevant, which means unfit to guide me in the world-environment, and thus to facilitate the elaboration of a certain project, producing a state of calm and satisfaction. would ascribe to Nietzsche also, namely of an ethics of praxis: an idea can be considered true when believing in it proves to be better, that is more advantageous in our lives (P 42). In this sense it is a good and just idea, and truth can be considered as a species of good. But we are far from the Platonic horizon: true is the opinion that is held as true in a certain historical period and for certain ends; true is the belief, the belief that has a value, that more effectively circulates inside a community, as a banknote, and that is embraced since it proves useful for the survival of the individual or of the species. Indeed, how to separate what is better for us to believe and what we must believe? Is it not true - as Peirce also stated - that logic is grounded on inherently ethical principles and it is rooted on a social principle? That is - as Nietzsche wrote - is it not true that logic is structured as such since it comes from a field that is not entirely logical? ${ }^{20}$

21 The blending of psychology and ethics that seems to pollute James' epistemology has been much criticised by those who ascribe themselves to the Peircean school of thought. But on the contrary, this blending is maybe the strength of this epistemology. James' insistence on affective and psychological themes is the same that was also present in Nietzsche, when he declared himself a psychologist ${ }^{21}$ or when he suggested to investigate the existence of a prehistory of "drives, inclinations, aversions" (GS 335) behind any judgement. Certainly James has never meant to advance a genealogy of morals, or of moral prejudices; and he has never used any idol-smasher hammer. Indeed, any philosopher has his own temper and his own weapons to fight the battle for truth.

Let us now put together what we have learned from James and what Nietzsche notices in relation to the theme of truth as belief: indeed it is surprising to see how even the words through which this hypothesis is presented - let alone their comments - are shared by the two great thinkers. 
"[T]hat there should be a large amount of faith, that it should be possible to pass definite judgments on things, and that there should be no doubt at all concerning all essential values. Thus it is necessary that something should be assumed to be true, not that it is true" (WP 507). If truth - as James clearly pointed out - is manufactured and not found, the will to truth demands the act of making true, of holding as true, of acting as if it were true. Indeed, will to truth - Nietzsche adds - is only a mask for will to power (that is then primarily creative power). To believe is the primordial trait in any sensible impression, "a sort of yea-saying" (WP 506); therefore the evaluation 'I believe that this and this other is this' has to be considered as an exact indication of the "essence of truth" (WP 507). This motive is present in the all of Nietzsche's work: to the one who objects that for as much as a thing is believed in, it does not become true, the answer is that truth is simply a form of belief that is manifested as a non-eliminable condition of life, that is of an expansion of one's own possibility of action (WP 532-3). The hypothesis that more than any other instills unto us a sense of security and strength is believed truer: its crystalline and coherent appearance is simply a projection of our strengthened and acquiesced soul. As a conclusion, the will to believe is nothing else than the will to power.

But which is the most valuable belief? It is the belief that something lasts and repeats itself - the author thinks -, that sound bases on which to build "facts" and theories can be individuated: that "logicising, rationalising, and systematising are of assistance as means of existence" (WP 552) (James wrote "helpful" P 42). To believe makes stronger, apter to life. "What is truth? - inertia; that hypothesis which brings satisfaction [...]" (WP 537). True is what resonates with a familiar tone and produces a pause in our questioning. The irritation due to doubt - Peirce said - induces a struggle to achieve a state of belief, something which represents the demi-cadence that closes a musical phrase in the symphony of our intellectual life. The only aim of the research is thus to establish an opinion, not necessarily a true opinion, but a stable, reassuring one. ${ }^{22}$ To bring something unknown back to something known "is comforting, reassuring, satisfying and produces a feeling of power, as well" (TI VII.5): it is not Peirce here who speaks, but Nietzsche - and it is only the word macht (power) that distinguishes him from the American thinkers. The pleasure of familiarity is the proof of the value of truth, the author goes on. The unknown produces indeed a sense of danger, of restlessness, and the first instinct is the one of suppressing this distressing state of the soul: the need to rationalize is simply the need for known things (this is the reason we always start from ourselves and in particular from our supposed interiority [...]). But then, "Is it not the instinct to fear that bids us to know?" (GS 355).

Here Nietzsche begins to weave his spider web around the cornerstone-propositions of metaphysics: what if the issue was not knowledge, but power? And what if the search for truth was not the point, but an impulse to dominate and control the existent was at stake instead? What if the impulse to truth should be considered first and foremost genealogically, in its moral and psychological aspects? The instinct that pushes us towards knowledge - Nietzsche writes in BGE 6 - is not the father of philosophy but only one of its instruments: the inclination to expansion, domination, power, reassurance and self- preservation prevails in thinking and constructing reasoning: needs that are all human, too human. Let us start with always asking ourselves "how the most remote metaphysical claims in a philosophy really arose [...]: What moral is it (is he-) aiming at?" (BGE 6). Reading the first essay by James in Pragmatism, "The Present Dilemma in 
Philosophy," with its well-known distinction between tender-minded and tough-minded souls, we will find a certain family resemblance (although not a sameness).

Concepts - Nietzsche realizes also - are only instruments "directed [...] at the appropriation of things" (WP 503), the apparatus of knowledge a pure mechanism that performs a task. "The object is not 'to know,' but to schematize, - to impose as much regularity and form upon chaos, as our practical needs require. In the formation of reason, logic, and the categories, it was a need in us that was the determining power: not the need 'to know,' but to classify, to schematize, for the purpose of intelligibility and calculation. [...] No preexisting 'idea' had anything to do with it: but utility, which teaches us that things can be reckoned with and managed, only when we view them roughly as equal [...] Finality in reason is an effect, not a cause [...] The categories are 'truths' only in the sense that they are the conditions of our existence, just as Euclid's Space is a conditional 'truth.' [...] [t]he instinct which makes us see the utility of concluding as we do conclude, is in our blood, we are almost this instinct [...] But what simplicity it is to attempt to derive a proof from this fact!" (WP 515). Is Nietzsche speaking here or James? Certainly, the issues at stake and the way of solving them are similar. I could go on quoting numerous aphorisms from the same period, $1884-88^{23}$ especially. Maybe the most revealing aphorism for tracing the identity of perspective of the two philosophers on this point is WP 514: the categories of reason - Nietzsche writes - were able to become dominant because they were functional to the survival even of the weakest ones. Their moral origin was forgotten, a sure sign of the origin becoming "master." Soon they were considered a priori. "And possibly, they may have been the expression of no more than a certain practicality, answering the ends of a race and species - their usefulness alone is their 'truth"' (WP 514, emphasis mine).

\section{Truth as Usefulness}

We have thus reached the theme that most of all has motivated the connection between the two authors in critical literature. We will see that if the - almost lexical - affinities are truly surprising, their research directions differ in an unavoidable way. Nietzsche talks of usefulness, advantage, value for life, in a way that certainly echoes James' work (e.g., WP 507), but exactly what kind of utility is that? And is it possible to equate truth and utility - an operation that for its apparent coarseness has provoked so many problems to the exegetes of James?

First of all, let us clarify that in Nietzsche "useful" is a linguistic term and as such it is metaphoric. Therefore it has to be determined in relation to a specific use, productive of finalities sometimes different from the expected ones. There are different species of usefulness, he writes in WP 647, in the aphorism titled "Against Darwinism," and that which is useful, for instance, to the duration of the individual, could be in fact damaging to its strength and its brightness. The usefulness of an organ does not explain its formation - as Darwin instead claimed - on the contrary! We have always to ask ourselves: "Useful in relation to what?"

There is especially one point on which the thoughts of the two authors seem far removed from one another. Let us read the aphorism 493: "Truth is that kind of error without which a certain species of living being cannot exist. The value for Life is ultimately decisive." This is the issue at stake for Nietzsche: if it is true that the value for life is a nontranscendable principle (and life - it has to be reminded - means the expansion of the will 
to power, in this case the power of the body and its "great reason"), this value does not necessarily coincide with what can be considered true logically, but it could also be error, falsification, mask, pure appearance, deception. Since On Truth and Lies in a Nonmoral Sense , the author has been arguing for the irrelevance of the questions connected to the distinction true/false, referring them instead to the distinction advantage/disadvantage. ${ }^{24}$ Thus truth - as Vahininger would write - can simply be considered as the most advantageous form of error. As a consequence, error can also appear as truth in itself, it is sufficient that it proves to be useful to somebody for something. ${ }^{25}$ "[A belief] might be a life-preserving belief and still be false" (WP 483). James certainly did not take this road. Although, if we read his writings carefully, it would be possible to infer a connection also at this level: indeed James moved beyond the distinction true/false, as we have seen, embracing the relevant (for somebody's interests)/ irrelevant one.

30 Anyway Nietzsche dares in an even more profound theoretical maelstrom: the falsity of judgment does not stand as an objection to it (BGE 4); on the contrary, without a perennial action of falsification - that is of metaphorisation of the existing that, as we have seen, is accomplished by logic and science, as well as by art and life, according to Nietzsche - it would not be possible to live. "We have arranged for ourselves a world in which we are able to live - by positing bodies, lines, planes, causes and effects, motion and rest, form and content, without these articles of faith no one could endure living! But that does not prove them true. Life is not an argument; the conditions of life might include error" (GS 121). To renounce to the creative exercise that weaves colourful mantles and repainted surfaces, an exercise that stays on the surface, in order not to see the depth of the cave on which we stand, that would mean to renounce to life: life wants errors, errors are a condition of life itself. Against the morality of reasonable utilitarianism, Nietzsche deploys the Apolonnian power of lies and their beautiful appearances. If life is becoming, then knowledge is impossible, since it changes meaning as soon as it is constituted, since it becomes error as soon as it is attested as being (WP 617) "To concede the fictional nature of the condition of life means of course taking a dangerous stand against the customary feelings about value. A philosophy which dares to do that is for this reason alone already standing beyond good and evil" (BGE 4).

Let us reconnect the threads of discussion without delving further in the complex theme of truth in Nietzsche, a theme that would require a much wider treatment. According to Nietzsche - as well as to James (and Peirce) - the "feeling of rationality" coincides with a state of rest of the thought, with an inertial state - we can say - in which the fear for the unknown is acquiesced and the faith in one's own certainties helps to survive without falling into the abyss of nihilism or scepticism. According to pragmatists, this process is not only necessary from a biological and epistemological point of view, but it is also an index of intellectual superiority. According to Nietzsche it has certainly played a role for instance - in the edification of the knowledge of science and metaphysics, where logic has proved to be a successful expedient to conduct a more prosperous and protected life. If the aim is "value for life," to talk of substance, subject, principle of non contradiction, sufficient reason, or causality, everything works perfectly, as long as it succeeds in granting strength to the ascending life, that life which does not accept to be petrified in a "pigeon-hole" of concepts. It is necessary, though, to be aware that it works because it is a work of fiction. That any interpretation (thus also logical, dialectical, metaphysical interpretations) is counterfeiting, a "fake," a "substitute" (P 120). In these statements, apparently similar, the distance between the two authors can be measured: according to 
James, a "substitute" is a creation that "stands for" something that, although existing, we will never be able to grasp; according to Nietzsche this "something" is a nothing at all: we find "[b]ehind every cave an even deeper cavern" (BGE 289); "we no longer believe that truth remains truth when one pulls off the veil" states the preface to the second edition of the Gay Science.

Usefulness should not thus be seen as a value in itself, as an indisputable consequence of the truth of being - as it seems to be in James - but as a function of the will to power, that is, in conclusion, as one of its masks. If truth coincides with usefulness, usefulness has a purely illusory character: it serves the constant lie with which life constantly moves beyond itself translating itself into power. Thus, paradoxically, also the idea of truth as correspondence to a reality in itself (adaequatio) can be useful for a certain period and for certain purposes. The important thing is that it be productive of a functional perspective, in other words that it is able to deceive us on our ability to dominate. Also in Nietzsche there is - all in all - a non-transcendable value: sure not the value of usefulness but of life that wants to expand itself. And life is ready, in order to gain more power, to immolate itself, in other words not to be useful to itself anymore.

Truth in conclusion is always the effect of a (winning) praxis. There is no truth in itself, there are variegated and multiform effects of truth. If this is the keystone of the pragmatist investigation, ${ }^{26}$ also in Nietzsche we find sparse, but robust, references to the praxeologic dimension of knowledge. The prevailing of perspectivism, indeed, should not be interpreted as a sheer primacy of the intellectual point of view; on the contrary, it has an "empiricist" meaning in the Jamesian sense: "A higher duty is to fix a goal and to mould facts according to it: that is, the interpretation of action, and not merely a transvaluation of concepts" (WP 605). We introduce a sense, we produce it, we create it. But not arbitrarily or intellectually: with our actions and their sensitive effects. The perspective is nothing else than the praxis, the form of life to which we are anchored (even in a biological sense), a praxis that implies the selection of features crucial in modifying the very same experiential terrain in which we enact this praxis. But saying that the perspective coincides with the praxis that we enact, with the infinite habits of reaction through which we trade with the world, we have asserted again, without any coercion, the connection between hermeneutics and pragmatism, between interpretation and action. Any perspective is first of all embodied in a way of action: "the deed - the deed is everything," ${ }^{27}$ and there is no legitimacy in thinking any subject as added to the event of the action, any being under the doing. "The interpretation of causality is an illusion [...] A 'thing' is the sum of its effects, synthetically united by means of a concept, an image" (WP 551). ${ }^{28}$ It is not difficult for those who know not only James but also Peirce to see, shining through this aphorism, a sketch of the pragmatic maxim: our idea of anything is the idea of its sensible effects, and any thought is translated into an action. Moreover, Nietzsche insists on pointing out the need to abandon "the faith in origin" and in the intention of the author, in order to consider the "backward working power" of success or failure of an enterprise, that is of its consequences as values of the action itself (BGE 32). ${ }^{29}$

But if to land in a belief means to perform a habit of reaction - as Peirce claimed - to this habit we adhere, welcoming it as if it were an instinct. Better, as if it were a faith. I will choose two aphorisms that I consider particularly significative of the pragmatic tonality of the author: they are written at 15 years of distance, as a testimony of Nietzsche's persistent inclination towards this plan of analysis. In 1872 he writes: "[Life] needs faith in truth, but in that case illusion is sufficient, that is 'truths' are demonstrated through 
their effects, not through logical demonstrations [...] What is true and what exercises an action is considered as identical." ${ }^{30}$ In the summer of 1887 , close to his psychological collapse, Nietzsche questions himself again on the real genesis of concepts and says: "this springs from practical spheres, from utilitarian spheres, hence the strong faith it commands (one is threatened with ruin if one's conclusions are not in conformity with this reason; but this fact is no "proof" of what the latter asserts)" (WP 579).

\section{Truth as Faith}

Let us then - in the end - consider maybe the most divulgative and popular text by James, the Will to believe. I will briefly synthesize the theses argued for in it, emphasizing the elements that - in my opinion - are most strongly echoed in Nietzsche. First of all, James claims that we adhere to a hypothesis, even in scientific domains, when we can make it come alive with the sap of our interest, an interest which has always a passional nature. According to the nice example by the author, if I refer to the Islamic Messiah, the Mahdi, this kind of idea does not induce in my listeners any significative reaction; instead in an Arab, it turns out to be a lively hypothesis that can lead him to move mountains: the value of an idea is attested by the "willingness to act," and the "faith" in it is embodied in the immediate and irrevocable action that follows from it. Any belief, in conclusion, has a fideistic component that ignites it and enables its perpetration. And this faith, or will to believe, is pragmatically will to act. A hypothesis that is not made alive by an active, favourite, passional - inherently pre-judiced, we could say - choice is a dead hypothesis, and consequently it has to be admitted that the emotional sphere is not at all extraneous to intellectual knowledge: actually it nourishes it and it enables it to hold, in many cases, those aspects of 'objectivity' and rigour that - as we have already noticed - are nothing else than specific emotive tonalities. Intellectual knowledge is not "what remains after wish and will and sentimental preference have taken wing" (WB 8), but, lived as a belief in truth, it answers to a deep need of our being. The non-intellectual nature of all our convictions is absolutely determining in making knowledge itself emerge and circulate.

Truth, far from being evidence, is not only a pure perspectival belief, it is also configured as an act of faith that expresses a deep desire of a pathic nature. We need truth, that is, we need to believe in order to act. Before knowing, there is the need to know, an absolutely vital need. And, is there any difference - James asks - between faith in God and faith in science? Maybe not that much, since they are all faiths, although of different character, unshakeable faiths that each of us embraces according to his own temperament. In this hall, the conference speaker reminds us, each of us blindly "believes" in the (admittedly invisible) presence of molecules and cells, he believes in those "things" that are democracy and progress [...] But are they facts or interpretations?

"Pure knowledge and pure logic" do not produce in themselves our beliefs which have an invariably passional nature: "our belief in truth itself, for instance, that there is a truth and that our minds and it are made for each other, - what is [this] but a passionate affirmation of desire, in which our social system backs up?" (WB 9). Nietzsche seems to echo James: "But this involves prejudice, it is a sign that truth does not enter the question at all [...] But what was needed was always belief - and not truth" (WP 455). Science itself reveals its ethical foundation when it establishes that the unceasing evaluation of facts and the corrections of the false beliefs are the supreme goods for the human being. The same insistence on pure logic, purified from any feeling, betrays that the absence of 
sentimentalism shares the same sentimental nature of the sentimentalism that it would want to be rid of.

It is thus in this plot of emotions, passions, capacities of affection, practical impulses and vital needs that intellectual reflection emerges. They prove to be dynamo-genic principles - as the author writes in other passages. ${ }^{31}$ And if "the faith in a fact can help create the fact" (WB 25) - that is, if any fact is declined as a value - the will to believe proves to be the will to power, that is the will to creative action, also for James.

Significantly, Nietzsche titled one of his most famous aphorisms "In what way we, too, are pious" (GS 344) and in its incipit it stages the same arguments as The Will to Believe by James. Science - they say - grants no right to citizenship to convictions; yet, it has to begin when the field has been emptied of any personal and passional conviction. Probably this is said with good reason - the author glosses - but we still have to ask ourselves if, "in order that this cultivation begin, must there not be some prior conviction - and indeed one so authoritative and unconditional that it sacrifices all other convictions to itself?" Thus, even "science rests on a belief," and there is no science or knowledge completely empty of assumptions..$^{32}$ The question if truth is necessary has an answer that is antecedent any other research and any other intellectual inquire, and this is exactly because it points out a need of a very different nature: the faith "that nothing is more needed than truth." As James claimed, also the scientist is a believer and one not very open to doubt.

Up until now - as easily noticed - the words of the two authors echo each other in tones, in arguments and even in lexicon. It is not possible to live without believing, it is not possible to live completely "sceptically," that is it is not possible to live without thinking that there is the (a) truth. We adhere to the perspective in which we believe as we adhere to our skin: to us it is the truth, and we are faithful to it. If true is "to hold true," it is also to want to hold as true, that is "to hold to it."

41 But then Nietzsche hits deeper with his hammer and asks: What does this unconditional will to truth hide? The will to not let oneself be deceived? The will to not deceive? The will to not deceive myself? And what is the feeling that shines through, here, what is the advantage, for life, that inspires such an impulse? Why in the end avoid deception? How many times in the course of life, of the individual and of the species, have we had demonstrations that deception serves life, more than truth itself? It is not thus a utilitarian calculation. And then why are we always speaking of things being true, good, fair, what is this a symptom of? It is not at all an epistemic, but a moral issue: "'Will to truth' does not mean 'I do not want to let myself be deceived' but - there is no alternative - 'I will not deceive, not even myself': and with this we stand on moral ground" (GS 344). A morality that conceals an unconscious will to death, because life is polytropos, varied, ambiguous, contradictory, deceiving. The man of truth is - in other words - the man of nihilism, the man that stiffens his own concepts - out of fear for becoming - until he makes them lifeless. Hypotheses - as James would have said - go from alive to dead. There is but one conclusion: "even we knowers of today, we godless anti-metaphysicians, still take our fire, too, from the flame lit by the thousand-year old faith, the Christian faith which was also Plato's faith, that God, that truth is divine [...] But what if this were to become more and more difficult to believe, if nothing more were to turn out to be divine except error, blindness, the lie - if God himself were to turn out to be our longest lie?" (ivi).

Behind the will to believe the face that the mask of certainty conceals unveils: the will not to believe, the will of illusion, even the will of deception. 

perspectival as it can be - always appears and stays at the centre of his research (cp. WB ch. 5), because he is a self-proclaimed empiricist who "preserves as cordial a relation with facts" (P 26) and, especially, since to refuse the hypothesis of God and of a metaphysical hope was impossible to him, a religious man, and moreover an optimistically hopeful man in the progress of humanity towards the better. ${ }^{33}$ Sometimes, however - as pragmatism itself teaches us - the finalities that one sets upon oneself do not coincide with the effects that are produced. In James' theses, in his refined and at the same time popular intellectual constructions, in the problems that he was able to spot, the themes of the coming new age were blossoming, first and foremost the one that Nietzsche summed up with the words "death of God": the loss of any value and any certainty, but, at the same time, the birth of "philosophers of the dangerous Perhaps" (BGE 2), that will be able to avoid the mermaids of the will to believe. Genealogy of Morals, that synthesizes a great deal of his thought, at least as regards the themes that I have sketched here, and through which he - at the same time - seems to hold his hand out to James and to his last theoretical proposals: "From now on, my philosophical gentlemen, let us protect ourselves better from the dangerous old conceptual fantasy which posits a 'pure, will-less, painless, timeless subject of cognition,' let's guard ourselves against the tentacles of such contradictory ideas as 'pure reason,' 'absolute spirituality,' 'knowledge in itself - those things which demand that we imagine an eye which simply can't be imagined, an eye without any direction at all, in which the active and interpretative forces are supposed to stop or be absent - the very things through which seeing first becomes seeing something. Hence these things always demand from the eye something conceptually empty and absurd. The only seeing we have is seeing from a perspective; the only knowledge we have is knowledge from a perspective. The more emotional affects we allow to be expressed in words concerning something, the more eyes, different eyes, we know how to train on the same thing, the more complete our "idea" of this thing, our "objectivity," will be. But to eliminate the will in general, to suspend all our emotions without exception - even if we were capable of that - what would that be? Wouldn't we call that castrating the intellect? [...]." ${ }^{34}$

\section{NOTES}

1. From the beginning already I should like to make this clear: to compare Nietzsche and James is not only a theoretical proposal, but it also seems to be a sound historiographical direction: indeed, both the authors were enthusiastic readers of Emerson, from whom in many cases they both drew inspiration. Ralph Waldo Emerson seems to be the root of the crenulated developments of a great part of pragmatism and - via Nietzsche - of a significant quantity of studies in the "continental" field. More work should be done - in my opinion - on this shared root. On the contrary, James knew little of Nietzsche. He had read some of his writings, since Nietzsche was mentioned in Harvard (Royce introduced Nietzsche to the North American academic world, with more appreciation of and attention to the German philosopher than James 
ever paid). Anyway, James' critique of Nietzsche's positions is very radical, while being restricted to certain pages of The Varieties of Religious Experience, where the themes related to ascetic moral, force and therefore anti-democraticity of Nietzsche emerge. The critical texts that treat the relations between the two authors are - to my knowledge - very few. Besides the already mentioned Rorty, who refers to Nietzsche and James specifically in Consequences of Pragmatism, Minnesota University Press, 1982 and in Contingency, Irony, and Solidarity, Cambridge University Press, 1989; we can refer to Hingst Kai-Michael, Perspektivism und Pragmatismus. Ein Vergleich auf der Grundlage der Warheitsbegriffe und Religionsphilosphien von Nietzsche und James, 1998. In Italy Sergio Franzese is the main investigator: cp. Nietzsche e l'America, edited by S. Franzese, ETS, Pisa, 2005, with an essay by Franzese on James lettore di Nietzsche, themes further elaborated in The Ethics of Energy, Ontos verlag, Frankfurt, 2008. However we should not forget the first pioneering researches by R. Berthelot. (Un romantisme utilitaire. Le pragmatisme chez Nietzsche e chez Poincaré, Alcan, Paris 1911), by J. Granier, (Le probléme de la verité chez Nietzsche, Seuil, Paris, 1966) and by W. Kaufmann, who hinted at this in his Nietzsche. Philosopher, Psychologist, Antichrist, Princeton UP, Princeton, 1968.

2. I have recently written about the relations between two other great representatives of these traditions, Peirce and Heidegger, in Ermeneutica e pragmatismo, CUEM, Milano, 2009. On these two authors cp. also C. Sini, Passare il segno, Il Saggiatore, Milano, 1981.

3. I quote from F. Nietzsche, The Will to Power. An attempted transvaluation of all values. Books one, two, three and four, in Oscar Levy, The Complete Works of Friedrich Nietzsche, 14-5. Edinburgh and London, T.N. Foulis, (Revised third edition 1925, published by The Macmillan Company), from now on WP followed by the number of the pseudo-aphorism.

4. I quote from W. James, Pragmatism. A New Name for some Old Ways of Thinking, in Pragmatism and The Meaning of Truth, Harvard University Press, Cambridge, 1978, from now on P followed by the page number.

5. Indeed, it is to be remembered that these are notes and sketches of thoughts that Nietzsche wrote for personal use and not for publication.

6. This example is "stolen" from Deleuze.

7. J.von Uexküll (1938), Theoretische Biologie, Berlin, p. 340-1, 121-2; my translation.

8. Cp. A. Orsucci (1992), Dalla biologia cellulare alle scienze dello spirito, Bologna, Il Mulino; F. Moiso (1993), La volontà di potenza di F. Nietzsche. Una riconsiderazione, in 'Aut Aut', 253, p. 119-36; B. Babich (1994), Nietzsche's Philosophy of Science, State University of New York; W. Müller-Lauter (1998), Physiologie de la volonté de puissance, Paris, Allia; F. Moiso (1999), Nietzsche e le scienze, Cuem, Milano; M. Ferraris (1999), Ontologia, in Nietzsche, Laterza, Roma-Bari; B. Stiegler (2001), Nietzsche et la biologie, Paris, PUF, (now in a new Italian translation, Negretto, Mantova, 2009, ed. by R. Fabbrichesi e F. Leoni).

9. Cp. On these topics C. Sini (2009), Da parte a parte. Apologia del relativo, ETS, Pisa.

10. H. Bergson (1911), Préface à W. James, Pragmatisme, Flammarion, Paris; now in La pensée et le mouvant, Paris, Alcan, (1934), "Sur le pragmatisme de James. Vérité et réalité", p. 275.

11. The author writes here: "In short: the essence of a thing is really only an opinion concerning that 'thing.' Or, better still; 'it is worth' is actually what is meant by 'it is,' or by 'that is'." (WP 556). 12. Cp. for instance Eracle al bivio. Semiotica e filosofia, Bollati Boringhieri, Torino, 2007.

13. F. Nietzsche, Beyond Good and Evil, translated by Judith Norman and edited by Rolf-Peter Horstmann, Cambridge, Cambridge University Press, 2002; from now on BGE followed by the number of the aphorism. In aphorism 598 from WP we can read - very significantly: “The belief that there is no such thing as truth, the Nihilistic belief, is a tremendous relaxation for one who, as a warrior of knowledge, is unremittingly struggling with a host of hateful truths. For truth is ugly." Thus for Nietzsche truth exists: it is the Dionysian ground of existence (cp. also BGE 143: the terrifying basic text of homo natura). But it is - evidently - an existence that is not existent, an endless falling of masks 
14. 1873, Friedrich Nietzsche. "On Truth and Lies in an Nonmoral Sense," in Philosophy and Truth: Selections from Nietzsche's Notebooks of the Early 1870's, ed. and trans. David Breazeale, New Jersey, Humanities Press, 1979.

15. $\mathrm{Cp}$ on this point C. H. Seigfried, William James's Radical Reconstruction of Philosophy, State University of New York Press, 1990.

16. F. Nietzsche. On the Genealogy of Morals, trans. Walter Kaufmann, NY, Vintage Books, 1967, sezione III, 24.

17. B. Babich, op. cit., Cap. I.

18. I have developed further this aspect of James' philosophy in its relation to Darwin in "Effetti di verità: la rivoluzione darwiniana e il suo impatto sul pragmatismo," Discipline filosofiche, 2009.

19. A theme that we found repeated in many passages in Nietzsche's notes, also. Cp. WP 499: “'Thinking' in a primitive (inorganic) state is to persevere in forms as in the case of the crystal. In out thought, the essential factor is the harmonizing of the new material with the old schemes (= Procustes' bed), the assimilation of the unfamiliar." The Darwinian influence on the two authors, in these passages, is evident (Chauncey Wright will insist exactly on this point, anticipating that exaptation that is so much talked about these days).

20. F. Nietzsche, The Gay Science, trans. J. Nauckhoff, Cambridge (Ma), Cambridge University Press, 2001, § 111; from now on GS followed by the aphorism number. "The predominant disposition [...] to treat the similar as identical - an illogical disposition for there is nothing identical as such - is what first supplied all the foundations for logic." And that was the case of the construction of the concept of substance, or of causality, also. "No living being would be preserved had not the opposite disposition - to affirm rather than suspend judgement, to err rather than wait, to agree rather than deny, to pass judgement rather than be fair.

21. Cp. The Prefaction by Friedrich Nietzsche. Twilight of the Idol, trans. R. J. Hollingdale, London, Penguin, 1968. From now on TI, followed by chapter number.

22. C.S. Peirce, The fixation of belief IPopular Science Monthly 12 (November 1877), 1-15. Now in C. S. Peirce, Collected Papers, Harvard University Press, Cambridge, 1931-35, 5.397. Cp. In particular paragraphs 3 and 4 and notice the many analogies with Nietzsche that can be found here too.

23. For instance: WP 501, 503, 513, 455, 567, 568, GS 110.

24. Cp. on this topic R. Brigati, La verità sospetta: per una lettura di Verità e menzogna in senso extramorale, "Segnali," 2009.

25. These themes are tackled and well clarified in one of the few texts dedicated to the "vital pragmatism" of Nietzsche: J. Granier (1966), Le problème de la vérité dans la philosophie de Nietzsche, Paris, Seuil.

26. In James' words: “The attitude of looking away from first things, principles, 'categories,' supposed necessities; and of looking towards last things, fruits, consequences, facts" (P 36); in Peirce's words, simple and inspired by the Bible: "From their fruits ye shall know them" ( Pragmatism, in The essential Peirce, Bloomington and Indianapolis, Indiana University Press, 1998, vol. 2, p. 401).

27. F. Nietzsche, On the Genealogy of morals, cit., I, 13.

28. Cp. also for instance: "Has anybody ever been able to testify to a force? No, but to effects, translated into a completely strange language" WP 620. But cp also: WP 551, 557, 558, 555, 585.

29. Cp. also W. James (1897), Will to Believe and other essays in popular philosophy, Longmans Green and Co. New York, London and Bombay, p. 17. From now on WB followed by the page number: "our great difference from the scholastic lies in the way we 'face.' The strength of his system lies in the principles, the origin, the terminus a quo of his thought; for us the strength is in the outcome, the upshot, the terminus ad quem. Not where it comes from, but what it leads to is to decide." 
30. I quote and translate from the Italian version: F. Nietzsche, Frammenti postumi. Vol. III, Adelphi, Milano, 1992, 19 (43).

31. W. James (1907), The Energies of Men, in "Science," N.S. 25, n. 635, 321-32.

32. On these topics we can find many other aphorisms of the same flavour. $\mathrm{Cp}$ for instance 333: "Yet in the final analysis, what is this intelligere other than the way we become sensible to the other three? A result of the different and conflicting impulses to laugh, lament and curse? Before knowledge is possible, each of these impulses must first have presented its one-sided view of the thing or event." Cp also on this topic: GS 345, BGE 1-2- 12, 24, 287; WP 455, 612, 556, 558.

33. In this article I was aiming at emphasizing the affinities between the two thinkers: I am willing to admit that just equal if not bigger are the differences that divide them, that I have only sketched here.

34. F. Nietzsche, On the Genealogy of Morals, cit., III, 12. 